\title{
Clinicopathological Study on the Effects of Momordica charantia on Streptozotocin-Induced Diabetic Wistar Rats
}

\author{
Mohammed Salem Moqbel, Fahad Abdullah Al-Hizab, Seif Mustafa Barakat* \\ Department of Pathology, College of Veterinary Medicine, King Faisal University, Al-Hassa, KSA \\ Email: *seifbrkt@gmail.com
}

How to cite this paper: Moqbel, M.S., AlHizab, F.A. and Barakat, S.M. (2017) Clinicopathological Study on the Effects of $M o$ mordica charantia on Streptozotocin-Induced Diabetic Wistar Rats. Open Journal of Veterinary Medicine, 7, 49-62.

https://doi.org/10.4236/ojvm.2017.75006

Received: April 11, 2017

Accepted: May 22, 2017

Published: May 25, 2017

Copyright $\odot 2017$ by authors and Scientific Research Publishing Inc. This work is licensed under the Creative Commons Attribution International License (CC BY 4.0).

http://creativecommons.org/licenses/by/4.0/

\begin{abstract}
Momordica charantia (MC) a traditional medicine used for the treatment of many disorders was fed to streptozotocin (STZ)-induced diabetic male Wistar rats at 2, 5 and $10 \%$ of the standard diet. Rats were then observed for 12 weeks before sacrificed. Immediately, tissues from liver, kidney and pancreas were taken for histopathological examination. Serum samples were analyzed to evaluate liver, kidney and pancreatic functions. In addition, blood samples were collected to analyze hematology parameters. The results of the present study indicate that oral doses of MC at $5 \%$ and $10 \%$ of the daily diet resulted in alleviation of the pancreatic, hepatic and renal dysfunction induced by diabetes. The improved pancreatic, hepatic and renal functions were judged by histopathological, hematological and serobiochemical parameters. In conclusion, the MC fruits may be used as an antidiabetic herbal medicine.
\end{abstract}

\section{Keywords}

Momordica charantia, Antidiabetic, Hematology, Serobiochemistry, Histopathology

\section{Introduction}

Diabetes Mellitus (DM) is a major metabolic disorder characterized by chronic hyperglycemia as a result of a relative or absolute lack of insulin or its actions [1] [2] [3] [4]. Polyuria, polydipsia, polyphagia, weight loss, fatigue, blurred vision, hypertension, obesity, nephropathy and cardiovascular disorders are the main 
symptoms of the disease [2]. Insulin-dependent diabetes mellitus (IDDM) or Type 1 is conventionally treated with exogenous insulin while the non-insulindependent diabetes mellitus (NIDDM) or Type 2 is treated with oral hypoglycemic drugs such as sulphonylureas and biguanides [5] [6].

It is estimated that in the year 2013 more than 382 million people worldwide had DM and 592 million people will subsequently have the disease in 2035 [7]. In the Kingdome of Saudi Arabia, the prevalence of diabetes mellitus among people is high and represents a major clinical and public health problem [8]. KSA is now classified by the International Diabetes Federation (IDF) to be among the top 10 countries globally with the highest projected prevalence of diabetes in 2011 (16.2\%) and $2030(20.8 \%)$ [9].

It has been shown that the oral hypoglycemic treatment has characteristic profiles of side effects [10] [11] [12]. Numerous herbal preparations have been shown to affect blood glucose levels through various mechanisms, although they are usually limited by toxicity, relative lack of efficacy and standardization of ingredients medications [11] [13] [14] [15]. One of the common medicinal plants is Momordica charnatia, which has been used in various traditional medicines [16].

Momordica charantia (MC) (Figure 1), a member of the Cucurbitaceae family, is known as bitter melon, bitter gourd and Karelia. It grows in tropical areas of the Amazon, East Africa, Asia, India, South America, and the Caribbean, and is used traditionally as both food and medicine. The seeds, fruit, leaves and root of the plant have been used in traditional medicine for diabetes mellitus, anti-obesity, antimicrobial infections, anti-inflammatory, anti-hypertensive and as cytotoxic agent for certain types of cancer [15] [17] [18] [19].

The hypoglycemic effects of MC have been investigated [15] [17] [20] [21] [22] [23] [24]. However, more research is needed to explain the hematological, serobiochemical and histopathological alterations associated with the use of MC as an antidiabetic herbal medicine.

\section{Materials and Methods}

\subsection{Plant Material}

Fresh green whole fruits of Momordica charantia (MC) were purchased from local markets in Al-Ahssa, Kingdom of Saudi Arabia. The fruits were sliced and then oven dried at $60^{\circ} \mathrm{C}$ temperature for 24 hours. The dried fruit slices were powdered then added to the powdered feed at 2, 5 and $10 \%$.

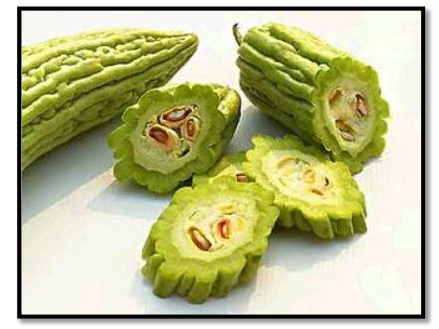

Figure 1. Momordica charantia fruit. 


\subsection{Chemicals}

Streptozotocin (STZ) single dose ( $85 \mathrm{mg} / \mathrm{kg}$ ) (Sigma, S0130-USA) freshly dissolved in $0.9 \%$ normal saline solution was injected intra-peritoneal to induce diabetes in all rats [25].

\subsection{Animals}

Fifty male Wistar albino rats weighing $(150-200 \mathrm{~g})$ were housed in hygienic fiberglass cages. Animals were fedon balanced commercial pellets. All rats were given two weeks adaptation period with free access to food and water before starting experimental procedures.

\subsection{Experimental Design}

Fifty rats were allotted at random to five groups, 10 rats each:

Group (0), negative control, given untreated diet and water ad-Libitum.

Group (1), positive control given STZ only.

Group (2), given STZ then fed with MC at $2 \%$ of the diet.

Group (3), given STZ then fed with MC at 5\% of the diet.

Group (4), given STZ then fed with MC at $10 \%$ of the diet.

At the end of the experiment (12 weeks) rats from each group were humanly sacrificed, blood samples were collected for serobiochemical and hematological analysis, gross lesions were recorded and tissue specimens from liver, kidney and pancreas were collected and fixed in $10 \%$ neutral buffered formalin for histopathological studies.

\subsection{Biochemical Analysis}

Blood samples were collected for biochemical parameters. Serum was separated by centrifugation of the clotted blood and stored at $-20^{\circ} \mathrm{C}$ till used. Samples were then analyzed for the activities of aspartate aminotransferase (AST), alanine aminotransferase (ALT), and alkaline phosphatase (ALP), as well as the concentration of cholesterol, total protein, albumin, globulin, total bilirubin, blood urea nitrogen (BUN), uric acid and creatinine, using Abaxis Vetscan VS2-America analyzer.

\subsection{Hematological Analysis}

Blood samples were collected in test tubes containing ETDA (Ethylene diamine tetra acetic acid) for determination of hemoglobin concentration (HGB), total erythrocyte count (TEC), packed cell volume (PCV), mean corpuscular volume $(\mathrm{MCV})$, mean corpuscular hemoglobin $(\mathrm{MCH})$, mean corpuscular hemoglobin concentration (MCHC) and total white blood cells (WBCs) using Abaxis Vetscan HM5-America analyzer.

\subsection{Histopathological Technique}

Tissue specimens from liver, kidney and pancreas were trimmed and put in the vacuum infiltrating tissue processing machine (Tissue-Tik VIP 5Jr. Japan) and 
embedded in paraffin wax by SLEE MPS/C machine, Germany. Specimens waxed blocks were sectioned to $5 \mu \mathrm{m}$ by LEICA RM 2235 microtome, Germany and then stained with Hematoxylin and Eosin (H\&E) for histopathological examination [26].

\subsection{Statistical Analysis}

Data were statistically evaluated with SPSS 7.5 software. All results were expressed as mean $\pm \mathrm{SD}[27]$.

\section{Results}

\subsection{Clinical Signs}

During the experimental time, group (1) and group (2) showed polyuria, polydipsia, polyphagia and weakness. Moreover, the mortality was approximately $50 \%$ in group (1) and $20 \%$ in group (2).

On the other hand, group (3) and group (4) showed gradual alleviation of polyuria and polyphagia without weakness and death in both groups. However, rats of group (0), negative control remained healthy throughout the days of experiment. They showed normal urine excretion, normal water intake and food consumption.

\subsection{Pathological Changes}

\subsubsection{Gross Findings}

Renal hypertrophy and liver congestion were common findings in group (1) and group (2).

\subsubsection{Microscopic Findings}

\section{1) Hepatic changes}

Liver tissues of the control untreated rats (Group 0) appear normal without any histological alterations, (Figure 2(a)). Coagulative necrosis and hepatocytomegaly were seen in rats given intraperitoneal injection $(85 \mathrm{mg} / \mathrm{kg})$ of STZ (Group 1), characterized by hyper eosinophilic cytoplasm with variable degree of nuclear size accompanied by margination of chromatin (Figure 2(b)). Rats treated with $2 \%, 5 \%$ and $10 \%$ of MC diet showed dose-dependent degree of recovery as shown in Figures 2(c)-(e) respectively.

\section{2) Renal changes}

In group (1), massive vacuolation was seen in cortical and medullar renal tubules, Figure 3(b) and Figure 3(c) respectively. Whereas, Rats treated with 2\%, $5 \%$ and $10 \%$ of MC diet showed dose-dependent degree of recovery of renal tubules, Figures 3(d)-(f) respectively. However, kidney tissues of the control untreated rats (Group 0) showed no any histopathological changes, (Figure 3(a)).

\section{3) Pancreatic changes}

The pancreatic tissues of the control untreated rats (Group 0), showed normal islets cells, (Figure 4(a)). However, prominent histopathological findings in 


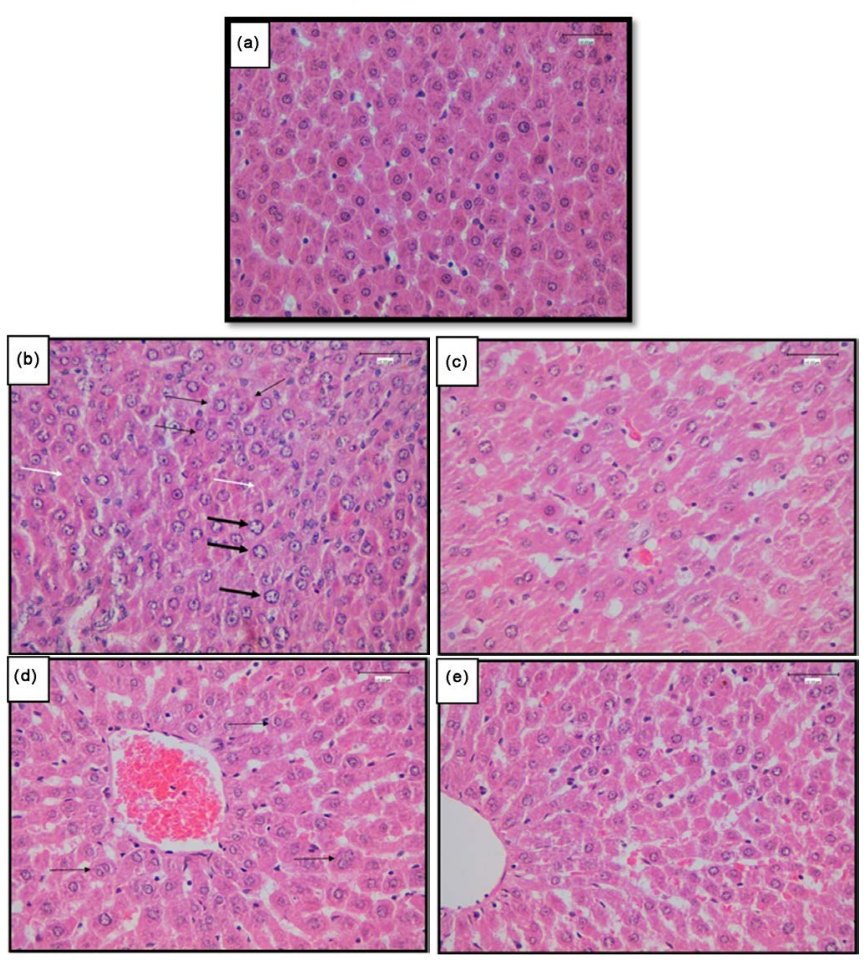

Figure 2. (a) Liver of normal rats (G0); (b) Liver of rats given STZ (G1) showing coagulative necrosis (white arrows) and hepatocytomegaly characterized by hyper eosinophilic cytoplasm with variation degree of nuclear size (thin arrows) and margination of chromatin (thick arrows); (c) Liver of rats given STZ and treated with $2 \% \mathrm{MC}(\mathrm{G} 2)$ showing slight recovery of hepatocytomegaly; (d) Liver of rats given STZ and treated with 5\% MC (G3) showing moderate recovery of hepatocytomegaly and hepatic regeneration characteristic by hepatocy ticbinucleation (arrows); (e) Liver of rats given STZ and treated with $10 \% \mathrm{MC}$ (G4) showing complete recovery of hepatocytomegaly. $\mathrm{HE} \times 40$.

pancreatic tissue were observed in the islets of Langerhans. Rats in group (1) showed necrosis, degeneration and disappearance of islets cells represented by empty spaces and few numbers of remaining cells (Figure 4(b)). All these pancreatic abnormalities were alleviated gradually in rats treated with $2 \%, 5 \%$ and $10 \%$ of MC diet as shown in Figures 4(c)-(f) respectively.

\subsection{Hematological Changes}

Rats in group (1) showed a significant decrease in the values of total erythrocyte count (TEC), hemoglobin concentration (HGB) and packed cell volume (PCV). Whereas, all treated rats in groups, (2, 3 and 4$)$ showed a significant gradual, dose-dependent increase in the values of Total Erythrocyte Count (TEC), hemoglobin concentration (HGB) and packed cell volume (PCV). It seems that total erythrocyte count (TEC), hemoglobin concentration (HGB) and packed cell volume (PCV) in rats of groups $3 \& 4$ were significantly higher than that of group 2, (Table 1). 


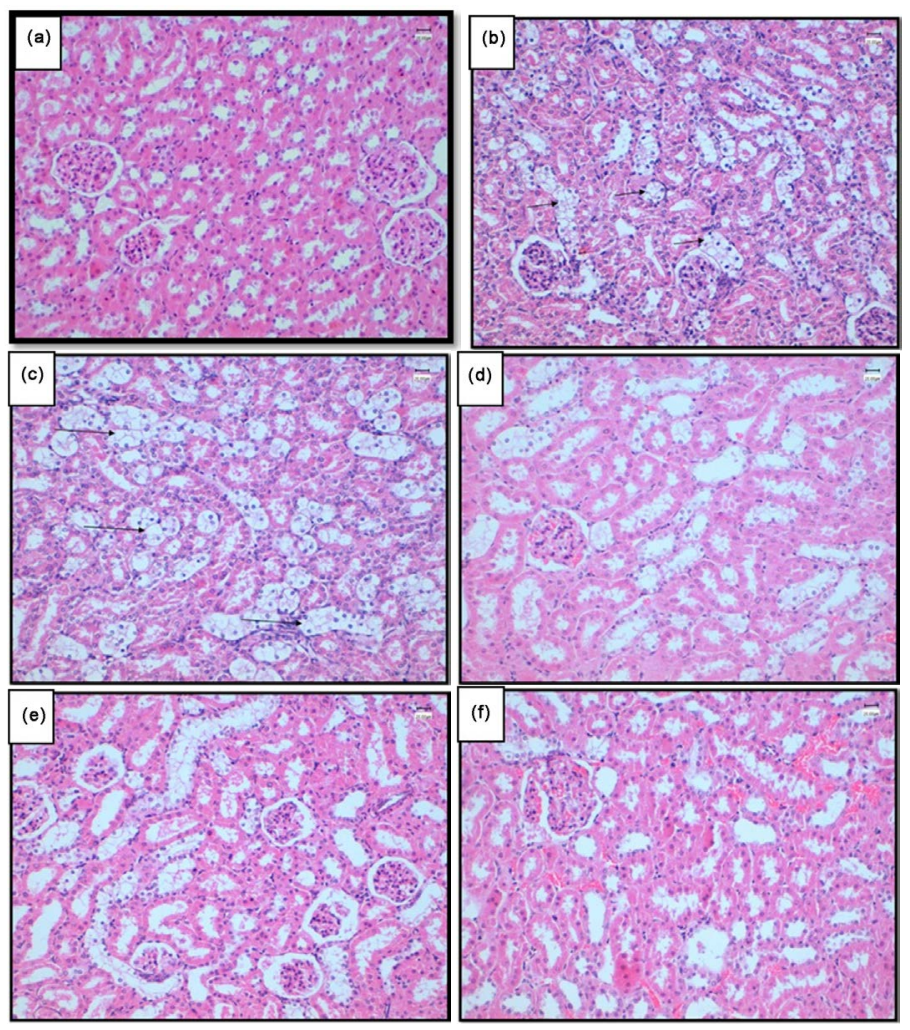

Figure 3. (a) Kidney of normal rats (G0); (b) Kidney of rats given STZ (G1) showing cortical vacuolation in proximal and distal renal tubules (arrows); (c) Kidney of rats given STZ (G1) showing medullar vacuolation in convoluted renal tubules and collected ducts (arrows); (d) Kidney of rats given STZ and treated with $2 \% \mathrm{MC}(\mathrm{G} 2)$ showing mild recovery of cortical vacuolation in proximal and distal renal tubules; (e) Kidney of rats given STZ and treated with 5\% MC (G3) Showing moderate recovery of cortical vacuolation in proximal and distal renal tubules; (f) Kidney of rats given STZ and treated with $10 \% \mathrm{MC}$ (G4) showing complete vacuolation recovery and appear to be normal. HE $\times 20$.

Table 1. Effect of Momordica charantia (MC) on hematological values in STZ-induced diabetic rats.

\begin{tabular}{cccccc}
\hline Haematological parameters & Group (0) & Group (1) & Group (2) & Group (3) & Group (4) \\
\hline TLC $\left[10^{3} / \mu \mathrm{l}\right]$ & $12.09 \pm 0.52^{\mathrm{a}}$ & $11.49 \pm 0.81^{\mathrm{a}}$ & $11.62 \pm 0.05^{\mathrm{a}}$ & $11.03 \pm 0.26^{\mathrm{a}}$ & $11.81 \pm 0.14^{\mathrm{a}}$ \\
LYM $\left[10^{3} / \mu \mathrm{l}\right]$ & $8.32 \pm 0.36^{\mathrm{a}}$ & $8.58 \pm 0.07^{\mathrm{a}}$ & $8.71 \pm 0.14^{\mathrm{a}}$ & $8.68 \pm 1.45^{\mathrm{a}}$ & $8.54 \pm 1.83^{\mathrm{a}}$ \\
MON $\left[10^{3} / \mu \mathrm{l}\right]$ & $0.35 \pm 0.17^{\mathrm{a}}$ & $0.37 \pm 0.65^{\mathrm{a}}$ & $0.36 \pm 0.23^{\mathrm{a}}$ & $0.37 \pm 0.61^{\mathrm{a}}$ & $0.36 \pm 0.34^{\mathrm{a}}$ \\
NEU $\left[10^{3} / \mu \mathrm{l}\right]$ & $2.79 \pm 0.79^{\mathrm{a}}$ & $2.21 \pm 0.38^{\mathrm{a}}$ & $2.46 \pm 0.26^{\mathrm{a}}$ & $2.40 \pm 0.61^{\mathrm{a}}$ & $2.80 \pm \mathrm{a} 0.80^{\mathrm{a}}$ \\
TEC $\left[10^{6} / \mu \mathrm{l}\right]$ & $8.93 \pm 0.25^{\mathrm{a}}$ & $4.74 \pm 0.22^{\mathrm{b}}$ & $6.17 \pm 0.87^{\mathrm{bc}}$ & $7.73 \pm 0.43^{\mathrm{bd}}$ & $8.88 \pm 0.14^{\mathrm{a}}$ \\
HGB $[\mathrm{g} / \mathrm{dl}]$ & $14.34 \pm 0.43^{\mathrm{a}}$ & $9.43 \pm 0.40^{\mathrm{b}}$ & $11.25 \pm 0.43^{\mathrm{bc}}$ & $12.65 \pm 0.61^{\mathrm{ac}}$ & $15.40 \pm 0.36^{\mathrm{ad}}$ \\
PCV & $49.3 \pm 1.35^{\mathrm{a}}$ & $26.84 \pm 1.39^{\mathrm{b}}$ & $42.59 \pm 1.48^{\mathrm{cd}}$ & $46.91 \pm 4.75^{\mathrm{ad}}$ & $50.33 \pm 0.54^{\mathrm{a}}$ \\
MCV [fl] & $53.25 \pm 1.18^{\mathrm{a}}$ & $56.50 \pm 2.53^{\mathrm{ac}}$ & $69.50 \pm 0.65^{\mathrm{b}}$ & $59.50 \pm 1.69^{\mathrm{dc}}$ & $56.60 \pm 0.51^{\mathrm{ac}}$ \\
MCH $[\mathrm{pg}]$ & $16.09 \pm 0.42^{\mathrm{a}}$ & $19.83 \pm 0.56^{\mathrm{bd}}$ & $18.23 \pm 1.52^{\mathrm{bd}}$ & $16.38 \pm 0.64^{\mathrm{a}}$ & $17.34 \pm 0.38^{\mathrm{a}}$ \\
MCHC $[\mathrm{g} / \mathrm{dl}]$ & $30.38 \pm 0.74^{\mathrm{a}}$ & $35.80 \pm 0.47^{\mathrm{b}}$ & $26.15 \pm 0.69^{\mathrm{c}}$ & $26.75 \pm 0.48^{\mathrm{c}}$ & $30.56 \pm 0.43^{\mathrm{a}}$ \\
PLT $\left[10^{3} / \mu \mathrm{l}\right]$ & $521.88 \pm 66.18^{\mathrm{a}}$ & $577.00 \pm 9.06^{\mathrm{a}}$ & $587.75 \pm 27.86^{\mathrm{a}}$ & $547.00 \pm 42.01^{\mathrm{a}}$ & $547.80 \pm 47.45^{\mathrm{a}}$ \\
\hline
\end{tabular}

Values are mean \pm standard error. Different letters between group means values are significant $(\mathrm{p} \leq 0.05)$. 

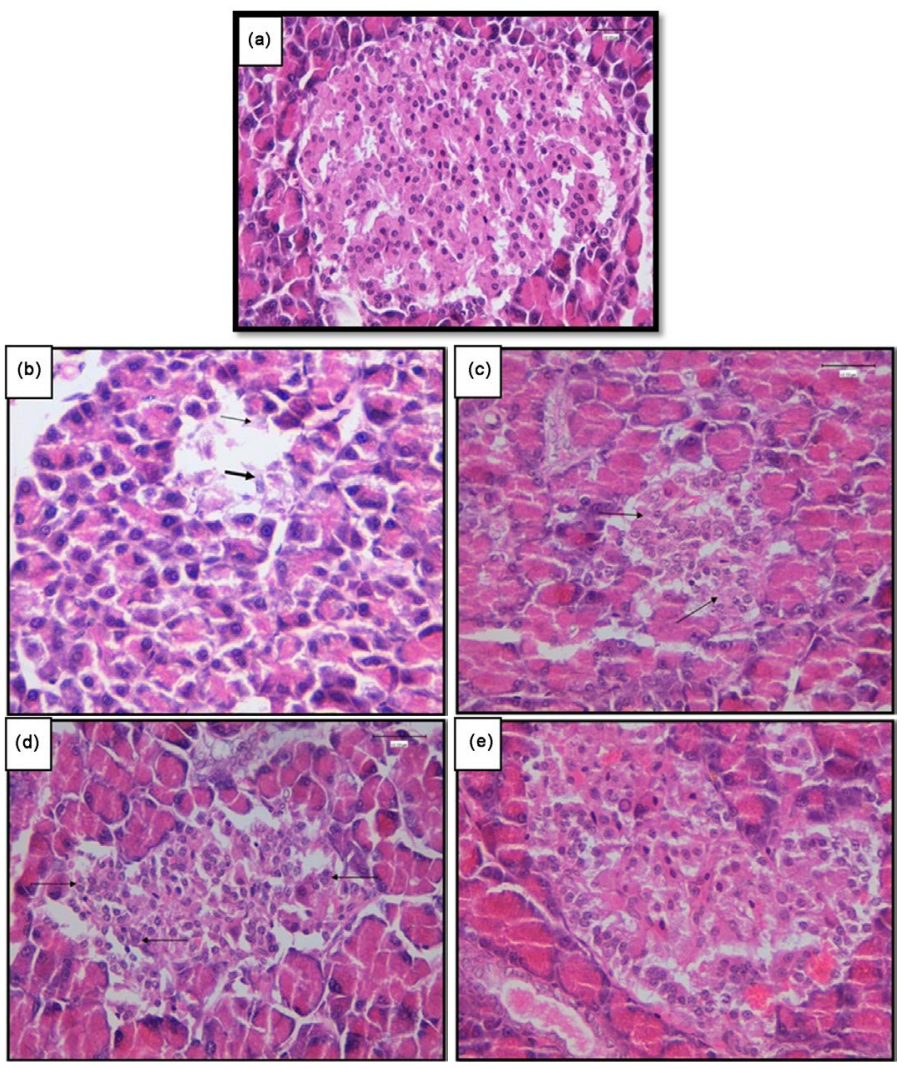

Figure 4. (a) Pancreatic islets cells of normal rats (G0); (b) Pancreatic islets cells of rats given STZ (G1) showing necrosis (thin arrow) and degeneration (thick arrow); (c) Pancreatic islets cells of rats given STZ treated with 2\% MC (G2) seen smaller in size and islets cells showing mild recovery with some necrosis (arrows); (d) Islets cells of rats given STZ treated with 5\% MC (G3) seen bigger in size and showing islets cells aggregation with binucleated (regeneration) (arrows); (e) Islets cells of rats given STZ treated with 10\% MC (G4) appear normal in size and highly cellular (abnormalities recovery). $\mathrm{HE} \times 40$.

\subsection{Serobiochemical Changes}

As shown in Table 2, rats in group (1) showed a significant ( $\mathrm{p} \leq 0.05)$ increase in the concentration of serum ALT, AST, ALP, cholesterol, glucose, BUN, creatinine and uric acid. Whereas, all treated rats in groups, (2, 3 and 4) showed gradual recovery represented by decreased values of serum ALT, AST, ALP, cholesterol, glucose, BUN, creatinine and uric acid. It has been observed that the recovery in all treated groups is related to the level of MC given. In addition, there is a significant difference $(\mathrm{p} \leq 0.05)$ in the values of these parmeters between rats treated with $5 \%$ and $10 \% \mathrm{MC}$, and rats treated with $2 \% \mathrm{MC}$.

\section{Discussion}

In the present study, polyuria, polydipsia, polyphagia, weakness and death were the common clinical signs observed in group 1 (given only STZ) and group 2 (given STZ then treated with $2 \% \mathrm{MC}$ ). However, alleviation of these clinical signs was observed in group 3 (given STZ then treated with 5\% MC) and group 4 
Table 2. Effect of Momordica charantia (MC) on serobioche micalvalues in STZ-induced diabetic rats.

\begin{tabular}{|c|c|c|c|c|c|}
\hline Biochemical parameters & Group (0) & Group (1) & Group (2) & Group (3) & Group (4) \\
\hline $\mathrm{ALT}[\mathrm{IU} / \mathrm{L}]$ & $39 \pm 1.96^{\mathrm{a}}$ & $272 \pm 10.75^{b}$ & $180.25 \pm 6.87^{c}$ & $88.17 \pm 5.65^{d}$ & $86.00 \pm 8.70^{d}$ \\
\hline AST [IU/L] & $67.54 \pm 3.73^{\mathrm{a}}$ & $119.75 \pm 7.36^{\mathrm{b}}$ & $96.63 \pm 9.76^{c}$ & $89.17 \pm 6.14^{\text {cd }}$ & $80.56 \pm 2.17^{\mathrm{ad}}$ \\
\hline ALP $[\mathrm{IU} / \mathrm{L}]$ & $131.11 \pm 6.16^{\mathrm{a}}$ & $1003.13 \pm 25.83^{\mathrm{b}}$ & $803.75 \pm 23.20^{\mathrm{bd}}$ & $776.50 \pm 30.30^{\mathrm{cd}}$ & $715.00 \pm 23.26^{\mathrm{cd}}$ \\
\hline T. Bilirubin [mg/dl] & $0.30 \pm 0.00^{\mathrm{a}}$ & $0.33 \pm 0.03^{\mathrm{a}}$ & $0.30 \pm 0.00^{\mathrm{a}}$ & $0.32 \pm 0.02^{\mathrm{a}}$ & $0.30 \pm 0.00^{\mathrm{a}}$ \\
\hline Cholesterol [mg/dl] & $60.78 \pm 3.41^{\mathrm{a}}$ & $127.75 \pm 8.87^{\mathrm{b}}$ & $101.25 \pm 6.34^{c}$ & $72.71 \pm 5.38^{\mathrm{a}}$ & $67.17 \pm 4.33^{\mathrm{a}}$ \\
\hline Glucose $[\mathrm{g} / \mathrm{dl}]$ & $117.67 \pm 3.21^{\mathrm{a}}$ & $582.00 \pm 18.47^{\mathrm{b}}$ & $478.00 \pm 15.88^{c}$ & $399.83 \pm 10.51^{d}$ & $291.00 \pm 13.19^{e}$ \\
\hline T. Protein $[\mathrm{g} / \mathrm{dl}]$ & $7.77 \pm 0.15^{\mathrm{a}}$ & $7.55 \pm 0.49^{\mathrm{a}}$ & $7.18 \pm 0.09^{\mathrm{a}}$ & $7.50 \pm 0.23^{\mathrm{a}}$ & $7.79 \pm 0.23^{\mathrm{a}}$ \\
\hline Albumin [g/dl] & $4.49 \pm 0.07^{\mathrm{a}}$ & $3.50 \pm 0.13^{\mathrm{ac}}$ & $4.05 \pm 0.17^{\mathrm{ac}}$ & $3.57 \pm 0.15^{\mathrm{ac}}$ & $3.63 \pm 0.40^{\mathrm{ac}}$ \\
\hline Globulin [g/dl] & $3.30 \pm 0.14^{\mathrm{a}}$ & $4.05 \pm 0.60^{\mathrm{ac}}$ & $3.08 \pm 0.24^{\mathrm{ad}}$ & $3.92 \pm 0.21^{\mathrm{ad}}$ & $4.19 \pm 0.26^{\mathrm{ac}}$ \\
\hline BUN $[\mathrm{mg} / \mathrm{dl}]$ & $17.67 \pm 0.71^{\mathrm{a}}$ & $37.14 \pm 3.89^{\mathrm{b}}$ & $32.25 \pm 0.85^{\mathfrak{c}}$ & $31.81 \pm 2.60^{c}$ & $28.50 \pm 3.97^{\mathrm{d}}$ \\
\hline Creatinine $[\mathrm{mg} / \mathrm{dl}]$ & $0.40 \pm 0.04^{\mathrm{a}}$ & $0.85 \pm 0.26^{b c}$ & $0.63 \pm 0.06^{\mathrm{ac}}$ & $0.58 \pm 0.03^{\mathrm{ac}}$ & $0.51 \pm 0.06^{\mathrm{a}}$ \\
\hline Uric acid [mg/dl] & $5.16 \pm 0.26^{\mathrm{a}}$ & $15.60 \pm 0.85^{\mathrm{b}}$ & $13.55 \pm 0.52^{\mathrm{bd}}$ & $12.20 \pm 0.18^{\mathrm{cd}}$ & $9.30 \pm 0.73^{\text {ce }}$ \\
\hline
\end{tabular}

Values are mean \pm standard error. Different letters between group means values are significant $(\mathrm{p} \leq 0.05)$.

(given STZ then treated with $10 \% \mathrm{MC}$ ). This finding may indicate that MC has promising effects in prevention as well as delay in progression of diabetic complications in rats. These results agree with that obtained by [22] [28] [29] [30].

Anemia is the most common blood disorder in diabetes mellitus [31] [32] [33] [34]. In the present study, rats in group 1 (given only STZ) showed anemia characterized by reduction of total erythrocyte count, (TEC), hemoglobin concentration (HGB) and packed cell volume (PCV). Whereas, all treated rats with $2 \%$, $5 \%$ and $10 \%$ MC, groups 2, 3 and 4 respectively, showed dose-dependent relief of anemia. This relief may be related with the antidiabetic effects of MC [15] [22] [25] [30] [35] [36].

Rats in group 1 (given only STZ) showed an increase in concentration of blood glucose (hyperglycemia). Whereas, all treated rats with $2 \%, 5 \%$ and $10 \%$ MC, groups 2, 3 and 4 respectively, showed remarkable recovery represented by gradual reduction of blood glucose. This finding is consistent with the results obtain by [15] [25] [35] [36] [37] [38]. In the present study, rats in group 1 (given only STZ) showed an increase in concentration of ALT, AST, ALP, cholesterol BUN, creatinine and uric acid. The increased levels of some intracellular enzymes like ALT, AST and ALP in diabetic animals could be attributed to the kidney and liver cell damage [39] [40] [41]. Moreover, the increment of lipid peroxidation has been found to be involved in the observed tissue damages in diabetic rats [38]. In addition, [42] observed increased levels of serum ALP in pathological conditions involving the kidneys. It has been reported that the increase in serum ALP might be derived from injury to the brush border membrane of the renal tubular cells and renal function impairment might also be responsible for the increased serum ALP [41]. Furthermore, the increased concentrations of creatinine, BUN and uric acid may be due to renal tissue injury [43].

In the present study, all treated rats with $2 \%, 5 \%$ and $10 \% \mathrm{MC}$, groups 2,3 and 4 respectively, showed remarkable decrease in the levels of ALT, AST, ALP, 
cholesterol BUN, creatinine and uric acid. The reduced levels of these intracellular enzymes after administration of MC to rats may be due to the alleviation of cell plasma membrane damage produced by diabetes. These findings were parallel with the results obtained by [35] [44] [45] [46].

Rats in group 1 (given only STZ) showed hepatocytomegaly and coagulative necrosis. These findings agree with the results obtained by [47]. Whereas, all treated rats with $2 \%, 5 \%$ and $10 \% \mathrm{MC}$, groups 2,3 and 4 respectively, showed dose-dependent alleviation of these hepatic lesions induced by STZ in rats. These results are consistent with the results obtained by [35] [48].

In diabetic rats, hyperglycemiais the main cause of nephropathy, indicated by glomerular hypertrophy [49], thickening of the glomerular basement membrane [41] [50] and tubular vacuolation [51]. Renal tubular vacuolation has been attributed to the hyperglycemia causing accumulation of glycogen in cellular cytoplasm [52]. In the present study, massive cortical and medullar tubular vacuolation was seen in group 1 (given only STZ). Whereas, all treated rats with 2\%, 5\% and $10 \% \mathrm{MC}$, groups 2, 3 and 4 respectively, showed gradual alleviation of these kidney lesions. These results are in line with [53] [54] [55].

In addition, [56] suggested that there is a correlation between the decrease in hyperglycemia, the reduction of oxidativestress, and the histopathological results of renal tissues. Hence, hypoglycemic and antioxidant effects of MC could improve kidney injury intreated diabetic rats.

The islets of Langerhans in group 1 (given only STZ) showed necrosis, degeneration and disappearance indicated by empty spaces and few numbers of remaining cells. These results are parallel with the results observed by [25] [57] [58]. Whereas, all treated rats with $2 \%, 5 \%$ and $10 \% \mathrm{MC}$, groups 2,3 and 4 respectively, showed gradual alleviation of these panceatic lesions represented by gradual recovery of islets indicated by increased sizes and regeneration. These results agree with the results obtained by [25] [57].

In conclusion, Momordica charantia (MC) fruits given at $5 \%$ and $10 \%$ of the daily standard diet for 3 months seem to possess beneficial effects on diabetic rats through alleviation of tissue injury and improvement of hematological and serobiochemical parameters. However rats given 2\% MC showed lower degree of improvement in hematological and biochemical parameters compared to the groups given 5\% and 10\% MC.

One of the limitations of such studies is the use of STZ at $(85 \mathrm{mg} / \mathrm{kg})$ to induce diabetes. This dose may cause harmful effects in organs other than the pancreas and may affect the serobiochemical findings specially glucose level. Therefore, the use of MC in animals with naturally occurring diabetes is preferred.

\section{Acknowledgements}

The researchers are grateful to Deanship of Scientific Research, King Faisal University (KFU), Saudi Arabia for funding this project. 


\section{References}

[1] Atkinson, M.A. and Maclaren, N.K. (1994) The Pathogenesis of Insulin-Dependent Diabetes Mellitus. New England Journal of Medicine, 331, 1428-1436. https://doi.org/10.1056/NEJM199411243312107

[2] Kumar, P. and Clark, M. (2002) Textbook of Clinical Medicine. Saunders Ltd., London, 1099-1121.

[3] Teixeira, C.C., Rava, C.A., Da Silva, P.M., Melchior, R., Argenta, R., Anselmi, F., Almeida, C.R.C. and Fuchs, F.D. (2000) Absence of Antihyperglycemic Effect of Jambolan in Experimental and Clinical Models. Journal of Ethnopharmacology, 71, 343-347. https://doi.org/10.1016/S0378-8741(00)00185-9

[4] YKI-Järvinen, H. (1994) Pathogenesis of Non-Insulin-Dependent Diabetes Mellitus. The Lancet, 343, 91-95. https://doi.org/10.1016/S0140-6736(94)90821-4

[5] Felig, P., Bergman, M. and Felig, C. (1995) The Endocrine Pancreas: Diabetes Mellitus. Endocrinology and Metabolism, 3, 1107-1250.

[6] Rosak, C. (2002) The Pathophysiologic Basis of Efficacy and Clinical Experience with the New Oral Antidiabetic Agents. Journal of Diabetes and Its Complications, 16, 123-132. https://doi.org/10.1016/S1056-8727(01)00207-0

[7] Guariguata, L., Whiting, D., Hambleton, I., Beagley, J., Linnenkamp, U. and Shaw, J. (2014) Global Estimates of Diabetes Prevalence for 2013 and Projections for 2035. Diabetes Research and Clinical Practice, 103, 137-149. https://doi.org/10.1016/j.diabres.2013.11.002

[8] Alqurashi, K., Aljabri, K. and Bokhari, S. (2011) Prevalence of Diabetes Mellitus in a Saudi Community. Annals of Saudi Medicine, 31, 19. https://doi.org/10.4103/0256-4947.75773

[9] Whiting, D.R., Guariguata, L., Weil, C. and Shaw, J. (2011) IDF Diabetes Atlas: Global Estimates of the Prevalence of Diabetes for 2011 and 2030. Diabetes Research and Clinical Practice, 94 311-321. https://doi.org/10.1016/j.diabres.2011.10.029

[10] Holman, R.R. and Turner, R.C. (1991) Oral Agents and Insulin in the Treatment of NIDDM. In: Pickup, J. and Williams, G., Eds., Textbook of Diabetes, Blackwell, Oxford, 467-469.

[11] Kameswara Rao, B., Giri, R., Kesavulu, M. and Apparao, C. (1997) Herbal Medicine in the Management of Diabetes Mellitus. Manphar Vaidhya Patrika, 1, 5.

[12] Williams, G. and Pickup, J. (1991) New Drugs in the Management of Diabetes Mellitus. In: Oxford University, Ed., JC Textbook of Diabetes II Blackwell, Oxford University, Oxford, 977-993.

[13] Kusamran, W., Ratanavila, A. and Tepsuwan, A. (1998) Effects of Neem Flowers, Thai and Chinese Bitter Gourd Fruits and Sweet Basil Leaves on Hepatic Monooxygenases and Glutathione S-Transferase Activities, and in Vitro Metabolic Activation of Chemical Carcinogens in Rats. Food and Chemical Toxicology, 36, 475-484. https://doi.org/10.1016/S0278-6915(98)00011-8

[14] Platel, K., Shurpalekar, K.S. and Srinivasan, K. (1993) Influence of Bitter Gourd (Momordica charantia) on Growth and Blood Constituents in Albino Rats. Food/ Nahrung, 37, 156-160. https://doi.org/10.1002/food.19930370210

[15] Virdi, J., Sivakami, S., Shahani, S., Suthar, A., Banavalikar, M. and Biyani, M. (2003) Antihyperglycemic Effects of Three Extracts from Momordica charantia. Journal of Ethnopharmacology, 88, 107-111. https://doi.org/10.1016/S0378-8741(03)00184-3 
[16] Atta-Ur-Rahman and Zaman, K. (1989) Medicinal Plants with Hypoglycemic Activity. Journal of Ethnopharmacology, 26, 1-55. https://doi.org/10.1016/0378-8741(89)90112-8

[17] Ahmed, I., Lakhani, M., Gillett, M., John, A. and Raza, H. (2001) Hypotriglyceridemic and Hypocholesterolemic Effects of Anti-Diabetic Momordica charantia (Karela) Fruit Extract in Streptozotocin-Induced Diabetic Rats. Diabetes Research and Clinical Practice, 51, 155-161. https://doi.org/10.1016/S0168-8227(00)00224-2

[18] Khan, M. and Omoloso, A. (1998) Momordica charantia and Allium Sativum: Broad Spectrum Antibacterial Activity. Korean Journal of Pharmacognosy, 29, 155-158.

[19] Matsuda, H., Li, Y., Murakami, T., Matsumura, N., Yamahara, J. and Yoshikawa, M. (1998) Antidiabetic Principles of Natural Medicines. III. Structure-Related Inhibitory Activity and Action Mode of Oleanolic Acid Glycosides on Hypoglycemic Activity. Chemical and Pharmaceutical Bulletin, 46, 1399-1403. https://doi.org/10.1248/cpb.46.1399

[20] Akhtar, M.S. (1982) Trial of Momordica charantia Linn (Karela) Powder in Patients with Maturity-Onset Diabetes. Journal of Pakistan Medical Association, 32, 106-107.

[21] Akhtar, M.S., Athar, M.A. and Yaqub, M. (1981) Effect of Momordica charantia on Blood Glucose Level of Normal and Alloxan-Diabetic Rabbits. Planta Medica, 42, 205-212. https://doi.org/10.1055/s-2007-971629

[22] Grover, J., Yadav, S. and Vats, V. (2002) Medicinal Plants of India with Anti-Diabetic Potential. Journal of Ethnopharmacology, 81, 81-100. https://doi.org/10.1016/S0378-8741(02)00059-4

[23] Jayasooriya, A.P., Sakono, M., Yukizaki, C., Kawano, M., Yamamoto, K. and Fukuda, N. (2000) Effects of Momordica charantia Powder on Serum Glucose Levels and Various Lipid Parameters in Rats Fed with Cholesterol-Free and CholesterolEnriched Diets. Journal of Ethnopharmacology, 72, 331-336. https://doi.org/10.1016/S0378-8741(00)00259-2

[24] Miura, T., Itoh, C., Iwamoto, N., Kato, M., Kawai, M., Park, S.R. and Suzuki, I. (2001) Hypoglycemic Activity of the Fruit of the Momordica charantia in Type 2 Diabetic Mice. Journal of Nutritional Science and Vitaminology, 47, 340-344. https://doi.org/10.3177/jnsv.47.340

[25] Abdollahi, M., Zuki, A., Goh, Y., Rezaeizadeh, A. and Noordin, M. (2011) Effects of Momordica charantia on Pancreatic Histopathological Changes Associated with Streptozotocin-Induced Diabetes in Neonatal Rats. Histology and Histopathology, $26,13$.

[26] Kiernan, J.A. (1999) Histological and Histochemical Methods: Theory and Practice. Shock, 12, 479. https://doi.org/10.1097/00024382-199912000-00012

[27] Snedecor, G. and Cochran, W.G. (1989) Statistical Methods. 8th Edition, Iowa State University Press, Ames, Iowa.

[28] Grover, J., Vats, V., Rathi, S. and Dawar, R. (2001) Traditional Indian Anti-Diabetic Plants Attenuate Progression of Renal Damage in Streptozotocin Induced Diabetic Mice. Journal of Ethnopharmacology, 76, 233-238. https://doi.org/10.1016/S0378-8741(01)00246-X

[29] Rathi, S., Grover, J. and Vats, V. (2002) The Effect of Momordica charantia and Mucuna Pruriens in Experimental Diabetes and Their Effect on Key Metabolic Enzymes Involved in Carbohydrate Metabolism. Phytotherapy Research, 16, 236-243. https://doi.org/10.1002/ptr.842 
[30] Rathi, S., Grover, J., Vikrant, V. and Biswas, N. (2002) Prevention of Experimental Diabetic Cataract by Indian Ayurvedic Plant Extracts. Phytotherapy Research, 16, 774-777. https://doi.org/10.1002/ptr.1064

[31] Daniele, S.M., Picena, J.C., Rodriguez, H., Montenegro, S.M., Tarres, M.C. and Martinez, S.M. (2012) Anemia in Spontaneously Type 2 Diabetic Rats With Renal Impairment. Journal of Endocrinology and Metabolism, 2, 171-175. https://doi.org/10.4021/jem122w

[32] Erukainure, O.L., Ebuehi, O.A., Adeboyejo, F.O., Aliyu, M. and Elemo, G.N. (2013) Hematological and Biochemical Changes in Diabetic Rats Fed with Fiber-Enriched Cake. Journal of Acute Medicine, 3, 39-44. https://doi.org/10.1016/j.jacme.2013.03.001

[33] Mahmoud, A.M. (2013) Hematological Alterations in Diabetic Rats Role of Adipocytokines and Effect of Citrus Flavonoids. EXCLI Journal, 12, 647-657.

[34] Thomas, M.C., Macisaac, R.J., Tsalamandris, C., Molyneaux, L., Goubina, I., Fulcher, G., Yue, D. and Jerums, G. (2004) The Burden of Anaemia in Type 2 Diabetes and the Role of Nephropathy: A Cross-Sectional Audit. Nephrology Dialysis Transplantation, 19, 1792-1797. https://doi.org/10.1093/ndt/gfh248

[35] Abdollah, M., Zuki, A., Goh, Y., Rezaeizadeh, A. and Noordin, M. (2010) The Effects of Momordica charantia on the Liver in Streptozotocin-Induced Diabetes in Neonatal Rats. African Journal of Biotechnology, 9, 5004-5012.

[36] El Batran, A.S., El-Gengaihi, S.E. and El Shabrawy, O.A. (2006) Some Toxicological Studies of Momordica charantia L. on Albino Rats in Normal and Alloxan Diabetic Rats. Journal of Ethnopharmacology, 108, 236-242. https://doi.org/10.1016/j.jep.2006.05.015

[37] Krawinkel, M.B. and Keding, G.B. (2006) Bitter Gourd (Momordica charantia): A Dietary Approach to Hyperglycemia. Nutrition Reviews, 64, 331-337. https://doi.org/10.1111/j.1753-4887.2006.tb00217.x

[38] Sathishsekar, D. and Subramanian, S. (2005) Beneficial Effects of Momordica charantia Seeds in the Treatment of STZ-Induced Diabetes in Experimental Rats. Biological and Pharmaceutical Bulletin, 28, 978-983. https://doi.org/10.1248/bpb.28.978

[39] Baynes, J.W. and Thorpe, S.R. (1999) Role of Oxidative Stress in Diabetic Complications: A New Perspective on an Old Paradigm. Diabetes, 48, 1-9. https://doi.org/10.2337/diabetes.48.1.1

[40] Can, A., Akev, N., Ozsoy, N., Bolkent, S., Arda, B.P., Yanardag, R. and Okyar, A. (2004) Effect of Aloe Vera Leaf Gel and Pulp Extracts on the Liver in Type-II Diabetic Rat Models. Biological and Pharmaceutical Bulletin, 27, 694-698. https://doi.org/10.1248/bpb.27.694

[41] Zafar, M., Naqvi, S., Ahmed, M. and Kaimkhani, Z.A. (2009) Altered Kidney Morphology and Enzymes in Streptozotocin Induced Diabetic Rats. International Journal of Morphology, 27, 783-790.

[42] Leibovitch, I., Ben-Chaim, J., Ramon, J. and Goldwasser, B. (1991) Increased Serum Alkaline Phosphatase Activity: A Possible Indicator of Renal Damage. Journal of Clinical Laboratory Analysis, 5, 406-409. https://doi.org/10.1002/jcla.1860050608

[43] Mardani, S., Nasri, H., Hajian, S., Ahmadi, A., Kazemi, R. and Rafieian-Kopaei, M. (2014) Impact of Momordica charantia Extract on Kidney Function and Structure in Mice. Journal of Nephropathology, 3, 35.

[44] Fernandes, N.P., Lagishetty, C.V., Panda, V.S. and Naik, S.R. (2007) An Experimental Evaluation of the Antidiabetic and Antilipidemic Properties of a Standar- 
dized Momordica charantia Fruit Extract. BMC Complementary and Alternative Medicine, 7, 29. https://doi.org/10.1186/1472-6882-7-29

[45] Hossain, M., Ahmed, M. and Islam, A. (2011) Hypolipidemic and Hepatoprotective Effects of Different Fractions of Methanolic Extract of Momordica charantia (Linn.) in Alloxan Induced Diabetic Rats. International Journal of Pharmaceutical Sciences and Research, 2, 601-607.

[46] Wehash, F., Abpo-Ghanema, I. and Saleh, R.M. (2012) Some Physiological Effects of Momordica charantia and Trigonella Foenum-Graecum Extracts in Diabetic Rats as Compared with Cidophage. World Academy of Science, Engineering and Technology, 64, 1206-1214.

[47] Kume, E., Ohmachi, Y., Itagaki, S.-I., Tamura, K. and Doi, K. (1994) Hepatic Changes of Mice in the Subacute Phase of Streptozotocin (SZ)-Induced Diabetes. Experimental and Toxicologic Pathology, 46, 368-374. https://doi.org/10.1016/S0940-2993(11)80119-3

[48] Ataman, J. and Idu, M. (2007) Histopathologic Effects of Methanolic Extract of Momordica charantia L. Leaves on the Liver of Wistar Rats. Trends in Medical Research, 2, 176-184. https://doi.org/10.3923/tmr.2007.176.184

[49] Koya, D., Hayashi, K., Kitada, M., Kashiwagi, A., Kikkawa, R. and Haneda, M. (2003) Effects of Antioxidants in Diabetes-Induced Oxidative Stress in the Glomeruli of Diabetic Rats. Journal of the American Society of Nephrology, 14, S250-S253. https://doi.org/10.1097/01.ASN.0000077412.07578.44

[50] Goumenos, D.S., Kawar, B., El Nahas, M., Conti, S., Wagner, B., Spyropoulos, C., Vlachojannis, J.G., Benigni, A. and Kalfarentzos, F. (2009) Early Histological Changes in the Kidney of People with Morbid Obesity. Nephrology Dialysis Transplantation, 24, 3732-3738. https://doi.org/10.1093/ndt/gfp329

[51] Shinde, U.A. and Goyal, R. (2003) Effect of Chromium Picolinate on Histopathological Alterations in STZ and Neonatal STZ Diabetic Rats. Journal of Cellular and Molecular Medicine, 7, 322-329. https://doi.org/10.1111/j.1582-4934.2003.tb00233.x

[52] Bamri-Ezzine, S., Ao, Z.J., Londoño, I., Gingras, D. and Bendayan, M. (2003) Apoptosis of Tubular Epithelial Cells in Glycogen Nephrosis during Diabetes. Laboratory Investigation, 83, 1069-1080. https://doi.org/10.1097/01.LAB.0000078687.21634.69

[53] Abdollahi, M., Zuki, A., Rezaeizadeh, A., Goh, Y. and Noordin, M. (2011) Effects of Momordica charantia Aqueous Extract on Renal Histopathological Changes Associated with Streptozotocin-Induced Diabetes Mellitus Type II in Neonatal Rats. Journal of Medicinal Plants Research, 5, 1779-1787.

[54] Kumar, G.S., Shetty, A. and Salimath, P. (2008) Modulatory Effect of Bitter Gourd (Momordica charantia LINN.) on Alterations in Kidney Heparan Sulfate in Streptozotocin-Induced Diabetic Rats. Journal of Ethnopharmacology, 115, 276-283. https://doi.org/10.1016/j.jep.2007.10.002

[55] Teoh, S., Latiff, A.A. and Das, S. (2010) Histological Changes in the Kidneys of Experimental Diabetic Rats Fed with Momordica charantia (Bitter Gourd) Extract. Romanian Journal of Morphology and Embryology, 51, 91-95.

[56] Martinez, G., Al-Dalain, S.M., Menendez, S., Guiliani, A. and Leon, O.S. (2005) Ozone Treatment Reduces Blood Oxidative Stress and Pancreas Damage in a Streptozotocin-Induced Diabetes Model in Rats. Acta Farmacéutica Bonaerense, 24, 491.

[57] Hafizur, R.M., Kabir, N. and Chishti, S. (2011) Modulation of Pancreatic $\beta$-Cells in Neonatally Streptozotocin-Induced Type 2 Diabetic Rats by the Ethanolic Extract of Momordica charantia Fruit Pulp. Natural Product Research, 25, 353-367. 
https://doi.org/10.1080/14786411003766904

[58] Jin, X., Zeng, L., He, S., Chen, Y., Tian, B., Mai, G., Yang, G., Wei, L., Zhang, Y. and Li, H. (2010) Comparison of Single High-Dose Streptozotocin with Partial Pancreatectomy Combined with Low-Dose Streptozotocin for Diabetes Induction in Rhesus Monkeys. Experimental Biology and Medicine, 235, 877-885.

https://doi.org/10.1258/ebm.2010.009361

Submit or recommend next manuscript to SCIRP and we will provide best service for you:

Accepting pre-submission inquiries through Email, Facebook, LinkedIn, Twitter, etc. A wide selection of journals (inclusive of 9 subjects, more than 200 journals) Providing 24-hour high-quality service

User-friendly online submission system Fair and swift peer-review system Efficient typesetting and proofreading procedure Display of the result of downloads and visits, as well as the number of cited articles Maximum dissemination of your research work

Submit your manuscript at: http://papersubmission.scirp.org/ Or contact ojvm@scirp.org 